Stochastics and Statistics

\title{
Effects of growth volatility on economic performance - Empirical evidence from Turkey ${ }^{\text {is }}$
}

\author{
M. Hakan Berument ${ }^{\mathrm{a}, *}$, N. Nergiz Dincer ${ }^{\mathrm{b}}$, Zafer Mustafaoglu $^{\mathrm{c}}$ \\ a Department of Economics, Bilkent University, 06800 Ankara, Turkey \\ ${ }^{\mathrm{b}}$ University of California, Berkeley and State Planning Organization, Turkey \\ ${ }^{\mathrm{c}}$ World Bank, 1818 H St., NW Washington, DC 20433, USA
}

\section{A R T I C L E I N F O}

\section{Article history:}

Received 1 December 2009

Accepted 15 September 2011

Available online 21 September 2011

\section{Keywords:}

Economics

Sustainability

Growth volatility

Total factor productivity

Investment

Real exchange rate

\begin{abstract}
A B S T R A C T
This paper examines the relationship between growth and growth volatility for a small open economy with high growth volatility: Turkey. Quarterly data for the period from 1987Q1 to 2007Q3 suggests that growth volatility reduces growth and that this result is robust under different specifications. This paper contributes to the literature by focusing on how growth volatility affects a set of variables that are crucial for growth. Empirical evidence from Turkey suggests that higher growth volatility reduces total factor productivity, investment, and the foreign currency value of local currency (depreciation). Moreover, it increases employment, though the evidence for this is not statistically significant.
\end{abstract}

Crown Copyright $\odot 2011$ Published by Elsevier B.V. All rights reserved.

\section{Introduction}

Discussion about the relationship between growth and growth volatility is old yet important. Although growth theory has been studied independently of business cycle theory for a long time, there has been growing interest in linking these two areas (see Ramey and Ramey, 1995 and references cited therein). The observed high volatility, especially in developing countries, has led economists to focus on understanding the relationship between growth and growth volatility. Neither theoretical nor empirical studies, however, have provided conclusive results. This study analyzes the effects of growth volatility on growth and contributes to the literature by focusing on how growth volatility affects a set of variables that is crucial for growth.

\footnotetext{
We would like to thank Anita Akkas, Erla Anderson, Rana Nelson and the anonymous referees for their helpful suggestions. An earlier version of the estimates for Turkey was published as a part of World Bank Country Memorandum for Turkey, and presented at the Economic Research Forum's 16th Annual Conference, Cairo, Egypt. The findings and conclusions in this paper are those of the authors and do not represent the views of the State Planning Organization of Turkey or the World Bank.

* Corresponding author. Tel.: +90 312290 2342; fax: +90 3122665140.

E-mail address: berument@bilkent.edu.tr (M.H. Berument).

URL: http://www.bilkent.edu.tr/ berument (M.H. Berument).
}

There are various motivations for this study. First, the paper looks at the effect of output growth volatility on output growth, which itself is an interesting question. Second, the paper analyzes possible transmission channels through which output volatility affects output growth. To the best of our knowledge, no study has explicitly assessed the role of growth volatility on a set of variables that is crucial to growth itself simultaneously (we call them transmitting variables), except for the role played by total factor productivity (TFP) and investment. In this regard, employing quarterly data from Turkey, we focus on TFP growth, investment (as a ratio to GDP), employment (employment growth), and the exchange rate (percentage of change in the real exchange rate) as possible transmission variables. Lower levels of TFP growth and investment are expected to lower GDP growth due to lower levels of productivity and lower levels of input. Lower levels of employment also decrease output growth due to lower levels of input to the production process. Depreciation or lower levels of exchange rate: (a) increases input cost and creates a cost-push mechanism to the production process by increasing prices and lowering output level; (b) may trigger tighter economic policies by the government; (c) weakens confidence of the economic agents, thus decreasing total spending; and (d) increases foreigncurrency-denominated liabilities of economic debt (see Kamin and Rogers, 2000 and Berument and Pasaogullari, 2003 for further discussion of this issue).

Turkey is an interesting country to study the above-mentioned questions in since it is a developing country suffering from high 
growth volatility. ${ }^{1}$ The variables considered for the transmission channel have a sufficient degree of flexibility and responsiveness to policy changes or market shocks. For instance, it would not be possible to analyze the impact of growth volatility on exchange rates in a currency board regime. Turkey is actively trying to increase its growth rate with the objective of converging with high-income European countries in a relatively short period. Increasing Turkey's growth rates through higher investment is possible but limited as the availability of domestic and foreign savings imposes constraints. Therefore, Turkey must also increase the efficiency of production factors. In this regard, understanding the dynamics between growth volatility and growth is an important policy question for Turkey and can be instructive for designing the right macroeconomic policies. Moreover, Turkey is an emerging market economy and a relevant case study for other developing countries. The analysis carried out in this paper and its conclusions could be valuable for other emerging market economies.

Our findings suggest that the effect of growth volatility on growth is negative, which supports the theoretical literature suggesting a negative relationship. An additional contribution of this paper shows that the negative impact works through the adverse effect of growth volatility on total factor productivity, investment, and exchange rates for Turkey.

Existing studies on output growth volatility and output growth are inconclusive in regards to the direction of effects. Different macroeconomic theorists have argued that output volatility has no effect, a positive effect, and a negative effect on output growth. Firstly, Friedman (1968) implicitly argues that output growth and output volatility are independent of each other; the output growth rate is determined by real factors such as labor skills and technology. The fluctuations of output are caused by a misallocation of resources that is triggered by price misperceptions due to monetary shocks. Speight (1999) provides empirical evidence that output volatility has a positive but insignificant effect on output growth rate.

Second, a positive effect of output volatility on growth can be justified by the argument that volatility is associated with recessions, which lead to higher research and development spending and/or the destruction of the least productive firms. This is the "creative destruction" view, which dates back at least to Schumpeter (1939). Shleifer (1986), Caballero and Hammour (1994), and Aghion and Saint Paul (1998) support this idea. Another argument for a positive effect is that more income volatility (uncertainty) leads to a higher savings rate (Sandmo, 1970) for precautionary reasons, and hence, a higher equilibrium economic growth rate.

Thirdly, a negative impact of output volatility on growth can be justified with theoretical underpinnings going back to Keynes (1936), who argues that entrepreneurs, when estimating the return on an investment, consider fluctuations in economic activity. Output fluctuations increase the perceived riskiness of investment projects and thus lower the demand for investment, which in turn reduces output growth. The literature on sunspot equilibria (Woodford, 1990) obtains a similar result. Theoretical analyses suggest that if investments cannot be reversed, then increased volatility may lead to lower investment (Bernanke, 1983; Pindyck, 1991; and Aizenman and Marion, 1993). Ramey and Ramey (1991) argue that if firms must commit to their technology in advance, then volatility could lead to lower mean output because these firms find themselves producing at suboptimal levels ex post.

\footnotetext{
1 The GDP growth rates of a set of comparable countries gathered from IMF-IFS for 1987Q1 to 2007Q3. The standard deviation and coefficient of variation of the counties are reported in parentheses: Turkey $(2.83,2.77)$, Chile $(1.48,1.04)$, Mexico $(1.42,1.79)$, Peru $(3.30,4.95)$, Philippines $(1.57,1.38)$, South Africa $(0.66,0.98)$, and South Korea $(1,73,1.13)$. The only country having a higher standard deviation and a higher coefficient of variation than Turkey is Peru.
}

If lower current output affects the accumulation of resources, then growth is adversely affected.

Empirical evidence on the direction of the effect of output volatility on output is also inconclusive (see, for example, Kormendi and Meguire, 1985; Grier and Tullock, 1989; Ramey and Ramey, 1995; Caporale and McKiernan, 1996, 1998; Fountas et al., 2004; Grier et al., 2004; and Norrbin and Yigit, 2005). The negative relationship between output growth volatility and output growth reported in this study is parallel to Ramey and Ramey (1995). The remainder of the paper is organized as follows: Section 2 presents the model, Section 3 discusses the data, Section 4 outlines the results, and Section 5 concludes.

\section{Modeling}

Modeling growth is a difficult task in time series analysis. A number of variables affect growth in a structural (behavioral) model framework. Employing a structural model is possible, however some econometric problems such as low degrees of freedom and endogeneity arise. As a solution, Sims (1980) suggests using lag values of dependent variables as explanatory variables (vector autoregressive models). Using autoregressive (AR) models we can capture the dynamics of the growth variable with lagged dependent variables. It is also plausible that growth rate is affected by growth variability. In order to capture growth volatility, one may use a non-linear specification such as an autoregressive conditional heteroskedastic $(\mathrm{ARCH})$ class of models. We therefore use an $\mathrm{ARCH}$ model to include the conditional variance of the residual $\left(\varepsilon_{t}\right)$ as $h_{t}$ in the growth equation:

Growth $_{t}=\beta_{0}+\sum_{i=1}^{n} \beta_{i}$ Growth $_{t-i}+\beta_{h} h_{t}+\varepsilon_{t}$,

where Growth $h_{t}$ is the growth rate at time $t, \varepsilon_{t}$ has a zero mean and a time-varying conditional variance of $h_{t}$ at the given information set at time $t-1, \Omega_{t-1}$ :

$\varepsilon_{t} / \Omega_{t-1} \sim\left(0, h_{t}\right)$.

Here $h_{t}$ captures the variability of growth. Nelson (1991) proposes the following model for the logarithm of the conditional variance:

$$
\begin{aligned}
\log h_{t}= & \varsigma+\sum_{j=1}^{p} P_{j} \log h_{t-j} \\
& +\sum_{j=1}^{q} \theta_{j}\left\{\left|\frac{\varepsilon_{t-j}}{\sqrt{h_{t-j}}}\right|-E\left|\frac{\varepsilon_{t-j}}{\sqrt{h_{t-j}}}\right|+\delta \frac{\varepsilon_{t-j}}{\sqrt{h_{t-j}}}\right\} .
\end{aligned}
$$

This model is referred to as the exponential-generalized autoregressive conditional heteroskedastic (EGARCH) model. If one interprets $P_{j}$ S as the coefficients of the lag values of the logarithm of the conditional variance, then the characteristic roots of the process should be outside the unit circle for the non-explosiveness of the conditional variance. The parameters $P_{j}$ capture the persistency of growth volatility. On the other hand, $\theta_{j} s$ are for how innovation to growth $\left(\varepsilon_{t}\right)$ will affect growth volatility. Since $\varepsilon$ 's are not autocorrelated, innovation to growth will not have a permanent effect except its feedback effect through $\log h_{t-j}$. The $\delta$ parameter is important here. If $\delta>0$, then a positive surprise increases volatility more than a negative surprise. If $-1<\delta<0$, a positive surprise increases volatility less than a negative surprise. If $\delta<-1$, then a positive surprise actually reduces volatility. Here the series $h_{t}$ is not a directly observable series but a generated series during the estimation process. Here Eqs. (1) and (2) are jointly estimated with a Maximum Likelihood method, where Eq. (2) reveals a generated conditional variance series (see Hamilton, 1994, pp. 657-665, for a discussion of this issue).

Nelson's (1991) specification models the logarithm of the conditional variance rather than the conditional variance, which 
Table 1

Growth and growth volatility.

\begin{tabular}{|c|c|}
\hline & Growth $_{t}$ \\
\hline Constant & $\begin{array}{l}1.0125^{* *} \\
(0.138)\end{array}$ \\
\hline Growth $_{t-1}$ & $\begin{array}{l}0.7892^{* *} \\
(0.017)\end{array}$ \\
\hline Growth $_{t-2}$ & $\begin{array}{l}0.1947^{* *} \\
(0.070)\end{array}$ \\
\hline Growth $_{t-3}$ & $\begin{array}{l}-0.1649 \\
(0.099)\end{array}$ \\
\hline Growth $_{t-4}$ & $\begin{array}{l}0.1008 \\
(0.074)\end{array}$ \\
\hline Growth volatility $_{t}$ & $\begin{array}{l}-0.040^{* *} \\
(0.518)\end{array}$ \\
\hline Constant & $\begin{array}{l}\text { Conditional variance } \\
-2.0034^{*} \\
(1.054)\end{array}$ \\
\hline $\log h_{t-1}$ & $\begin{array}{l}0.5468 \\
(0.381)\end{array}$ \\
\hline$\left\{\left|v_{t-1}\right|-E\left|v_{t-1}\right|+\delta v_{t-1}\right\}$ & $\begin{array}{l}-1.3983^{* *} \\
(0.663)\end{array}$ \\
\hline$\left\{\left|v_{t-2}\right|-E\left|v_{t-2}\right|+\delta v_{t-2}\right\}$ & $\begin{array}{l}-0.6508 \\
(0.783)\end{array}$ \\
\hline$\delta$ & $\begin{array}{l}0.3757^{*} \\
(0.217)\end{array}$ \\
\hline Log likelihood & 4.9711 \\
\hline
\end{tabular}

Note: Standard errors are reported under the corresponding estimated coefficients in parentheses.

* Denotes $10 \%$ significance.

** Denotes $5 \%$ significance.

provides some advantages. One advantage of the EGARCH model is that the variance $\left(h_{t}\right)$ itself will be positive, regardless of whether the $P_{j}$ and $\theta_{j}$ coefficients are positive or negative. This makes numerical optimization simpler and allows for a more flexible class of possible dynamic models of the variance (Hamilton, 1994, pp. 668-669). Moreover, this specification allows asymmetry to be measured through the leverage effect (positive and negative innovations to growth specification affect volatility differently).

In order to permit interaction between growth and the transmission variables, multi-AR models are used instead of vector-AR specifications. The conventional vector-AR model uses the lag values of all elements in an $X$ vector to explain the behavior of each variable in the $X$ vector. Specifically, if $X$ includes growth, TFP, employment, exchange rate, and investment, then in the first equation the right-hand side will include their lag values, thus putting too many variables on that side to explain growth and each of these variables and thereby lowering the degrees of freedom. Moreover, note that TFP, investment (as a ratio to GDP), and growth all use GDP in their calculations. A non-linear relationship exists among these variables. Due to the high collinearity among these variables (multicollinearity), estimates will also be less efficient if we use a vector-AR specification.

In order to account for this, we suggest the following:

(i) Instead of modeling all these variables simultaneously, two variables are modeled at a time. The first variable is growth, to extract the growth volatility, and the second variable is one of TFP, investment, exchange rate, and employment variables. If we had only one variable set ( $X_{t}$ includes only one variable), this model would be similar to Speight's (1999) work and the references cited therein.

(ii) Each variable is modeled with its own lags rather than the lags of other variables, to stop the high collinearity among each set of variables from affecting the results.
Next, the effects of the conditional variance of growth on a set of variables, including TFP, investment, exchange rate, and employment, are examined using the following specification:

$z_{t}=\gamma_{0}+\sum_{i=1}^{n} \gamma_{i} z_{t-i}+\gamma_{h} h_{t}+\eta_{t}$

where $z_{t}$ is the variable for TFP, investment, exchange rate, or employment. Specifically, growth is regressed on its own lag and the conditional variance of growth, and each of the TFP, investment, exchange rate, and employment variables is regressed on its own lag and the conditional variance of growth. Then, we assess how the conditional variance of growth rates affects growth itself as well as each of the TFP, investment, exchange rate, and employment variables. Eqs. 1, 3 , and 4 could be estimated individually. Pagan (1984) argues that using generated variables from a stochastic process in an estimation process could lead to biased estimates. Pagan and Ullah (1988) suggest using Full Information Maximum Likelihood estimates to avoid biased estimates. Therefore, Eqs. 1, 3, and 4 are estimated jointly using the Full Information Maximum Likelihood estimation method with the Broyden, Fletcher, Goldfarb, and Shanno algorithm.

\section{Data}

The data set used in this paper is quarterly data for Turkey from 1987Q1 to 2007Q3. ${ }^{2}$ The GDP growth, investment, and employment data are from the Turkish Statistical Institute (TURKSTAT). The investment variable used in the model is the ratio of investment to GDP, while GDP growth is the logarithmic first difference of real GDP. Total factor productivity, the usual Solow residual from a Cobb-Douglas-type production function with constant returns to scale, was obtained from the State Planning Organization of Turkey and is calculated using the OECD methodology with the assumptions of Cihan et al. (2005). The real exchange rate is calculated in terms of US dollars and deflated with the US All Urban Consumer Price Index, where an increase in the index represents (real) appreciation. All the series enter into the analysis in their logarithmic first difference form, except investment; investment is entered in the analysis as its ratio to GDP. All data are seasonally adjusted.

\section{Estimates}

Table 1 reports the relationship between the pace of growth and growth volatility for Turkey. ${ }^{3}$ Growth volatility is captured by the $\operatorname{EGARCH}(1,2)$ specification of conditional variance under generalized error distribution. ${ }^{4,5}$ The estimates of the parameters for the first growth equation include constant term, the first four lags of growth,

\footnotetext{
2 The Turkish Statistical Institute made a methodological change in calculating the national account data starting at the begining of 2008. It is important to note that it is not easy to combine these two data sets for extending the period as they are based on different methodologies. As GDP based on the new methodology is around 30\% higher in nominal terms than with the previous method, we use the previous version of the national accounts data, which covers the period 1987Q1-2007Q3.

${ }^{3}$ An earlier version of the estimates for Turkey was reported as part of the World Bank's (2006) Country Economic Memorandum for Turkey.

${ }^{4}$ The EGARCH model can be estimated using Maximum Likelihood by specifying a density for $\frac{\varepsilon_{t}}{\sqrt{h_{t}}}$. Nelson proposes the following functional form using generalized error distribution, normalized to have zero mean and unit variance for the distribution function of the error term: $f\left(\frac{\varepsilon_{t}}{\sqrt{h_{t}}}\right)=\frac{D \exp \left[-(1 / 2)\left|\frac{\varepsilon_{t}}{\sqrt{h_{t}}} / \lambda\right|^{D}\right]}{\lambda \cdot \cdot^{[D+1 / D D} \Gamma(1 / D)}$, where $\Gamma($.$) is the gamma$ distribution, $\lambda$ is a constant given by $\lambda=\left[\frac{2^{(-z / D)} \Gamma(1 / D)}{\Gamma(3 / D)}\right]^{1 / 2}$, and $\mathrm{D}$ is a positive parameter determining the thickness of the tails. For $D=2$, the equation becomes the standard Normal density. If $D<2$, the density has thicker tails than the Normal, but for $D>2$, it has thinner tails.

5 The lag orders of the EGARCH specifications are determined such that standard-
} ized errors are no longer autocorrelated. 
Table 2

Growth models for Turkey.

\begin{tabular}{|c|c|c|c|c|}
\hline & $\begin{array}{l}\text { I } \\
\text { Growth }\end{array}$ & $\begin{array}{l}\text { II } \\
\text { Growth }\end{array}$ & $\begin{array}{l}\text { III } \\
\text { Growth }\end{array}$ & $\begin{array}{l}\text { IV } \\
\text { Growth }\end{array}$ \\
\hline $\begin{array}{l}\text { Panel A: Growth specificat } \\
\text { Constant }\end{array}$ & $\begin{array}{l}1.8558^{* *} \\
(0.080)\end{array}$ & $\begin{array}{l}1.1847^{* *} \\
(0.001)\end{array}$ & $\begin{array}{l}1.0975^{* *} \\
(0.026)\end{array}$ & $\begin{array}{l}0.8262^{* *} \\
(0.055)\end{array}$ \\
\hline Growth $_{t-1}$ & $\begin{array}{l}-0.1001^{* *} \\
(0.042)\end{array}$ & $\begin{array}{l}-0.0522^{* *} \\
(0.010)\end{array}$ & $\begin{array}{l}0.0101 \\
(0.060)\end{array}$ & $\begin{array}{l}-0.1108 \\
(0.199)\end{array}$ \\
\hline Growth $_{t-2}$ & $\begin{array}{l}-0.0073 \\
(0.049)\end{array}$ & $\begin{array}{l}0.0076^{* *} \\
(0.002)\end{array}$ & $\begin{array}{l}-0.0110 \\
(0.025)\end{array}$ & \\
\hline Growth $_{t-3}$ & $\begin{array}{l}0.0077 \\
(0.038)\end{array}$ & $\begin{array}{l}-0.0144 \\
(0.010)\end{array}$ & $\begin{array}{l}0.0027 \\
(0.025)\end{array}$ & \\
\hline Growth $_{t-4}$ & & $\begin{array}{l}-0.1138^{* *} \\
(0.006)\end{array}$ & & \\
\hline \multirow[t]{2}{*}{ Growth volatility $_{t}$} & $\begin{array}{l}-0.0786^{* *} \\
(0.014)\end{array}$ & $\begin{array}{l}-0.0101^{* *} \\
(0.000)\end{array}$ & $\begin{array}{l}-0.0385^{* *} \\
(0.004)\end{array}$ & $\begin{array}{l}-0.0209^{* *} \\
(0.023)\end{array}$ \\
\hline & $Z_{t}=T F P$ & $Z_{t}=$ Investment & $Z_{t}=$ Depreciation & $Z_{t}=$ Employment \\
\hline \multicolumn{5}{|c|}{ Panel B: Transmission Variable (Estimated equation: $Z_{t}=\gamma_{0}+\Sigma \gamma_{i} Z_{t-i}+\gamma_{h 1} h_{t}+\eta_{t}$ ) } \\
\hline Constant & $\begin{array}{l}1.2231^{* *} \\
(0.100)\end{array}$ & $\begin{array}{l}2.0193^{* *} \\
(0.082)\end{array}$ & $\begin{array}{l}2.3017^{* *} \\
(0.640)\end{array}$ & $\begin{array}{l}0.3851 \\
(0.969)\end{array}$ \\
\hline$Z_{t-1}$ & $\begin{array}{l}-0.0711 \\
(0.046)\end{array}$ & $\begin{array}{l}0.9401^{* *} \\
(0.003)\end{array}$ & $\begin{array}{l}0.2459^{* *} \\
(0.083)\end{array}$ & $\begin{array}{l}-0.0226^{* *} \\
(0.171)\end{array}$ \\
\hline$Z_{t-2}$ & $\begin{array}{l}-0.0126 \\
(0.065)\end{array}$ & & $\begin{array}{l}-0.1373^{*} \\
(0.075)\end{array}$ & $\begin{array}{l}0.0229 \\
(0.261)\end{array}$ \\
\hline$Z_{t-3}$ & & & $\begin{array}{l}-0.1392^{* *} \\
(0.069)\end{array}$ & \\
\hline Growth volatility $t_{t}$ & $\begin{array}{l}-0.0786^{* *} \\
(0.014)\end{array}$ & $\begin{array}{l}-0.046^{* *} \\
(0.011)\end{array}$ & $\begin{array}{l}-0.2128^{* *} \\
(0.085)\end{array}$ & $\begin{array}{l}0.0005 \\
(0.023)\end{array}$ \\
\hline $\begin{array}{l}\text { Panel C: Conditional varian } \\
\text { Constant } \\
\text {. }\end{array}$ & $\begin{array}{l}0.9443^{* *} \\
(0.009)\end{array}$ & $\begin{array}{l}0.5839^{* *} \\
(0.001)\end{array}$ & $\begin{array}{l}0.3038^{* *} \\
(0.003)\end{array}$ & $\begin{array}{l}1.0118^{* *} \\
(0.012)\end{array}$ \\
\hline $\log h_{t-1}$ & $\begin{array}{l}0.5298^{* *} \\
(0.005)\end{array}$ & $\begin{array}{l}0.6303^{* *} \\
(0.000)\end{array}$ & $\begin{array}{l}0.8378^{* *} \\
(0.001)\end{array}$ & $\begin{array}{l}0.5141^{* *} \\
(0.006)\end{array}$ \\
\hline$\left\{\left|v_{t-1}\right|-E\left|v_{t-1}\right|-\delta v_{t-1}\right\}$ & $\begin{array}{l}0.0607^{* *} \\
(0.023)\end{array}$ & $\begin{array}{l}-0.4110^{* *} \\
(0.038)\end{array}$ & $\begin{array}{l}0.0045 \\
(0.102)\end{array}$ & $\begin{array}{l}-0.0691 \\
(1.550)\end{array}$ \\
\hline$\left\{\left|v_{t-2}\right|-E\left|v_{t-2}\right|-\delta v_{t-2}\right\}$ & $\begin{array}{l}0.3545^{* *} \\
(0.020)\end{array}$ & $\begin{array}{l}-0.9468^{* *} \\
(0.022)\end{array}$ & $\begin{array}{l}-0.5260^{* *} \\
(0.068)\end{array}$ & $\begin{array}{l}-1.3175 \\
(0.059)\end{array}$ \\
\hline$\delta$ & $\begin{array}{l}0.6044^{* *} \\
(0.068)\end{array}$ & $\begin{array}{l}0.3610^{* *} \\
(0.015)\end{array}$ & $\begin{array}{l}0.4135^{* *} \\
(0.073)\end{array}$ & $\begin{array}{l}0.3856 \\
(0.072)\end{array}$ \\
\hline Log likelihood & -159.7752 & -159.3787 & -268.7702 & -168.6483 \\
\hline
\end{tabular}

Note: Standard errors are reported under the corresponding estimated coefficients in parentheses.

* Denotes $10 \%$ significance.

** Denotes 5\% significance.

and the conditional variance of growth (growth volatility). ${ }^{6}$ In the first part of Table 1, the coefficient of growth volatility in the equation is negative and statistically significant at the five percent level, ${ }^{7}$ which suggests that growth volatility adversely affects growth for Turkey. Here the growth volatility measure $\left(h_{t}\right)$ is between 0.0067 and 0.2145 and averages 0.0755 . The negative estimated coefficient is consistent with Bernanke (1983), Pindyck (1991), Ramey and Ramey (1991, 1995), Aizenman and Marion (1993), Martin and Rogers (1997), Caballero (2000), and Talvi and Végh (2000). Similar to the AR specification, the coefficients for the lag values of the growth variable are not interpreted because they are used to capture the dynamics of the series. For the estimates of the EGARCH specifications, the lag value of the logarithmic conditional variance $\left(\log h_{t-1}\right)$

\footnotetext{
${ }^{6}$ The order of the AR process is determined by the final prediction error (FPE) criteria. Jansen and Cosimona (1988) argue that autocorrelated residuals wrongly indicate the presence of the ARCH effect. The FPE criteria determine the optimum lag such that the residuals are no longer autocorrelated; thus the selection of the FPE eliminates this problem.

7 The level of significance is at five percent, unless otherwise noted
}

is positive and less than one, suggesting that the conditional variance is non-explosive (Hamilton, 1994). ${ }^{8}$ The estimated coefficient for $\delta$ is positive and significant at the $10 \%$ level. This suggests that positive shocks increase volatility more than negative shocks for Turkey.

After we obtain the negative relationship between GDP and GDP volatility, we consider four variables that are crucial for growth using the two-variable multi-AR-ARCH models. The estimates of the model are reported in Table 2 . Each column of Table 2 corresponds to one of the four transmission variables: TFP, investment, depreciation, and employment, since Eqs. 1, 3 and 4 are estimated jointly.

Panel A of Table 2 reports the estimates of the growth specification, panel B reports the estimates of the transmission variable, and panel $C$ shows the estimates of the conditional variance specification of the growth equation. Column 1 of Table 2 reports the estimates that use GDP growth and the first transmission vari-

\footnotetext{
${ }^{8}$ We also conducted a set of non-parametric robustness tests that did not reject our specification. These tests are available from the authors on request
} 
able that we consider: TFP. The estimated growth equation includes the first three lags of growth and the conditional variance of growth (growth volatility). ${ }^{9}$ Note that the estimated coefficient for growth volatility is negative and statistically significant in the growth equation. This same finding in Table 1 indicates that growth volatility has an explanatory power for growth. Coefficients for the constant term and the lag values of growth were not interpreted the same way as in an AR specification, as these are used to capture the datagenerating process. We will not elaborate on the effect of growth volatility on growth and measures of growth volatility when we incorporate the other transmission variables, but the results are robust.

In panel B, the next set of coefficients reported in column 1 is for the transmission variable TFP. As suggested by the FPE criteria, TFP is modeled with a constant term, its two lags, and growth volatility. The estimated coefficient for growth volatility is negative and statistically significant. This suggests that uncertainty in growth decreases TFP, which is consistent with the theory of a negative relationship between volatility and growth through the productivity channel (see Martin and Rogers, 1997; and Talvi and Végh, 2000).

The second column of Table 2 is for the analysis that uses GDP growth and investment as a second transmission variable. Panel B of column 2 is for the investment equation. The estimated coefficient for growth volatility is statistically significant and negative (i.e., growth volatility decreases investment), suggesting that growth volatility decreases output via investment. This supports the irreversible investment argument of Bernanke (1983), Pindyck (1991), Dangl (1999), and Alvarez and Keppo (2002) and the empirical study by Aizenman and Marion (1999).

Column 3 reports the estimates for the relationship between growth volatility and real exchange rate changes, a rarely discussed issue in the literature. The equation for the real exchange rate change in column 3 includes its lags and growth volatility (panel B). The estimated coefficient of growth volatility is negative and statistically significant. Note that the real exchange rate change is the real value of the percentage change in the foreign currency value of the Turkish lira; thus lower values of the exchange rate indicate depreciation. This suggests that growth volatility decreases the real value of the Turkish lira. Higher volatility may increase demand for foreign currency for domestic residents and possible speculative attacks. ${ }^{10}$ Higher depreciation may also lower the output growth. ${ }^{11}$

\footnotetext{
9 The lag orders for growth and transmission variables are chosen using FPE criteria. The specification of the conditional variance equation is the same as the one reported in Table 1.

${ }^{10}$ Agents hold a basket of foreign currencies in their portfolios for their daily transactions and savings in Turkey. Due to religious reasons, agents do not want to charge interest to each other for (a) future payments of current deliveries or for (b) lending/borrowing purposes. Since daily depreciations were dictated by the central bank with a predictable narrow margin for most of our sample and inflation was high (annual inflation was 53.5 percent for the sample that we consider) agents held foreign currency (see Berument, 2007, for further elaboration on this issue). In orde for agents to satisfy their obligations, their need for foreign currency increases during volatile periods that are associated with higher output volatility. Thus, currency depreciates during these volatile periods. Further, higher volatility (uncertainty) increases the probability of a speculative attack on an existing exchange rate regime (see Prati and Sbracia, 2010) or agents demand foreign currency to hedge themselves against future policy shocks, thus depreciating This is currency.

11 From the viewpoint of classical economics, when Marshall-Lerner conditions are satisfied, the devaluation will lead to an improvement in the current account, hence an increase in aggregate demand. However in the short run, contractionary effects of devaluation on the non-tradable sector may balance or even be larger than these effects. The various channels that explain the contractionary effects of devaluations are discussed in Kamin and Rogers (2000) and in Berument and Pasaogullari (2003) for the particular case of Turkey. Following a devaluation nominal rigidities in the economy would cause real variables to decrease; external debt and foreign currency denominated liabilities would increase and cause expenditures to decrease due to budget constraints; confidence would decrease and lower aggregate demand; capital account outflows would limit growth and economic policies targeting low inflation could be contractionary.
}

The last column in Table 2 lets us examine the effects of growth volatility on employment. Estimates in panel B suggest that in contrast to the previous specifications, growth volatility has a positive estimated coefficient in the employment equation. The coefficient is not statistically significant, however. The labor market is not flexible in Turkey due to the existence of high non-wage labor costs, such as payroll taxes and high severance payments (Turkey pays one of the highest rates of the OECD countries). A considerable amount of informal employment and real wage flexibility are partly a result of this rigidity. Therefore, it is plausible that during business cycle downturns firms are able to renegotiate real wages in exchange for providing job security.

Panel $C$ reports the estimate of the conditional variance of the specification of the growth equation. The estimated coefficients for the lag values of the logarithm of the conditional variance are always less than one. Observing a coefficient of less than one satisfies the non-explosiveness of the conditional variance (Hamilton, 1994). The estimated coefficients for $\left\{\left|v_{t-1}\right|-E\left|v_{t-1}\right|+\delta v_{t-1}\right\}$ and $\left\{\left|v_{t-2}\right|-E\left|v_{t-2}\right|+\delta v t-2\right.$ have alternating signs across specifications. The negative coefficients for $\left\{\left|v_{t-i}\right|-E\left|v_{t-i}\right|+\delta v_{t-i}\right\}$ do not violate the non-negativity of the conditional variance because the logarithm of $h_{t}$ (which can be negative) is modeled, not $h_{t}$ itself.

In our specification, we model GDP growth as an ARCH process, but do not allow a time-dependent variance for the other (transmission) variables. Allowing a time-dependent variance for the other variables would lead to over-parameterization of the system. Since the effect of volatility in TFP, investment, exchange rate, and employment on other variables is not our main concern, we do not model the volatilities of other variables.

\section{Conclusion}

Using quarterly data from $1987 \mathrm{Q} 1$ to $2007 \mathrm{Q} 3$, we analyze the relationship between growth and growth volatility. Our estimates suggest that there is a negative relationship between growth and growth volatility for Turkey and that this result is robust through different specifications. This finding provides support for previous empirical results (Ramey and Ramey, 1995; among others).

The next step was to examine the effects of growth volatility on transmission variables. The literature suggests the presence of more transmission channels, including consumption (Mirman, 1971), political instability (Alesina et al., 1996), and level of financial development (Caballero and Hammour, 1994). We focus on the supply channels. The empirical evidence gathered here suggests that growth volatility decreases TFP and investment and depreciates the exchange rate for Turkey.

\section{References}

Aghion, P., Saint Paul, G., 1998. Uncovering some causal relationships between productivity growth and the structure of economic fluctuations: A tentative survey. Labor $12,279-303$.

Aizenman, J., Marion, N., 1993. Policy uncertainty, persistence, and growth. Review of International Economics 1 (2), 145-163.

Aizenman, J., Marion, N., 1999. Volatility and investment: Interpreting evidence from developing countries. Economica, 157-179.

Alesina, A., Ozler, S., Roubini, N., Swagel, P., 1996. Political instability and economic growth. Journal of Economic Growth 2, 189-213.

Alvarez, L.H.R., Keppo, J., 2002. The impact of delivery lags on irreversible investment under uncertainty. European Journal of Operational Research 136 (1), 173-180.

Bernanke, B.S., 1983. Irreversibility, uncertainty and cyclical investment. Quarterly Journal of Economics 98 (1), 85-106.

Berument, H., 2007. Measuring monetary policy for a small open economy: Turkey. Journal of Macroeconomics 29, 411-430.

Berument, H., Pasaogullari, M., 2003. Effects of the real exchange rate on output and inflation: Evidence from Turkey. Developing Economies 41 (4), 401-435.

Caballero, R.J., 2000. Macroeconomic volatility in Latin America: A view and three case studies. Economica 1 (1), 31-108, Reprinted in Estudios de Economia, 28(1), 5-52, June 2001. 
356

M.H. Berument et al./European Journal of Operational Research 217 (2012) 351-356

Caballero, R.J., Hammour, M.L., 1994. The cleansing effect of recessions. The American Economic Review 84 (5), 1350-1368.

Caporal, T., McKiernan, B., 1996. The relationship between output variability and growth: evidence from post war UK data. Scottish Journal of Political Economy 43, 229-236.

Caporale, T., McKiernan, B., 1998. The Fischer Black hypothesis: Some time-series evidence. Southern Economic Journal 64, 765-771.

Chan, C., Saygili, S., Yurtoglu, H., 2005. Turkiye ekonomisinde sermaye birikimi verimlilik ve buyume: 1972-2003. The Turkish State Planning Organization, Ankara, Turkey, p. 2686.

Dangl, T., 1999. Investment and capacity choice under uncertain demand. European Journal of Operational Research 117 (3), 415-428.

Friedman, M., 1968. The role of monetary policy. American Economic Review 58, 1 17.

Fountas, S., Karanasos, M., Mendoza, A., 2004. Output variability and economic growth: The Japanese case. Bulletin of Economic Research 48, 1749-1778.

Crier, K., Henry, O., Olekalns, N., Shields, K., 2004. The asymmetric effects of uncertainty on inflation and output growth. Journal of Applied Econometrics 19 (5), 551-565.

Crier, K., Tullock, G., 1989. An empirical analysis of cross-national economic growth, 1951-1980. Journal of Monetary Economics 24, 259-276.

Hamilton, J.D., 1994. Time Series Analysis. Princeton University Press, Princeton, NJ. Jansen, D.W., Cosimona, T.F., 1988. Estimates of the variance of US. Inflation based upon the ARCH model: comment (in notes, comments, replies). Journal of Money Credit and Banking 20 (3), 409-421.

Karin, Steven B., Rogers, John H., 2000. Output and the real exchange rate in developing countries: An application to Mexico. Journal of Development Economics 61 (1), 85-109.

Keynes, J.M., 1936. The General Theory of Employment, Interest, and Money. Macmillan, London.

Kormendi, R., Meguire, P., 1985. Macroeconomic determinants of growth: Crosscountry evidence. Journal of Monetary Economics 16, 141-163.

Martin, P., Rogers, C.A., 1997. Stabilization policy, learning by doing, and economic growth. Oxford Economic Papers 49 (2), 152-166.
Airman, L., 1971. Uncertainty and optimal consumption decisions. Econometrica 39, 179-185.

Nelson, D.B., 1991. Conditional heteroskedasticity in asset returns: A new approach. Econometric 59, 347-370.

Norrbin, S.C., Yigit, F.P., 2005. The robustness of the link between volatility and growth of output. Review of World Economics 141 (2), 343-356.

Pagan, A., 1984. Econometric issues in the analysis of regressions with generated regressors. International Economic Review, 221-247.

Pagan, A., Ullah, A., 1988. The econometric analysis of a model with risk terms. Journal of Applied Econometrics, 87-105.

Pindyck, R., 1991. Irreversibility, uncertainty and investment. Journal of Economic Literature 29 (3), 1110-1148.

Prati, Alessandro, Sbracia, Massimo, 2010. Uncertainty and currency crises: Evidence from survey data. Journal of Monetary Economics 57 (6), 668-681.

Ramey, G., Ramey, V., 1991. Technology Commitment and the Cost of Economic Fluctuations, NBER No. 3755.

Ramey, G., Ramey, V., 1995. Cross-country evidence on the link between volatility and growth. American Economic Review 85 (5), 1138-1150.

Sandmo, A., 1970. The effect of uncertainty on saving. Review of Economic Studies 37, 312-320.

Schumpeter, J.A., 1939. Business cycle: A theoretical, historical, and statistical analysis of the capitalist process. McGraw-Hill, New York.

Shleifer, A., 1986. Implementation cycles. Journal of Political Economy 94 (6), 11631190 .

Sims, C.A., 1980. Macroeconomics and reality. Econometric 48 (1), 1-48.

Speight, A., 1999. UK output variability and growth: Some further evidence. Scottish Journal of Political Economy 46, 175-184.

Talvi, E., Végh, C.A., 2000. Tax Base Variability and Procyclical Fiscal Policy, NBER Working Paper No. 7499.

Woodford, M., 1990. Learning to believe in sunspots. Econometric 58, 277-307. World Bank, 2006. Turkey: Country Economic Memorandum, Promoting Sustained Growth and Convergence with the European Union. World Bank, Washington DC. 